\title{
The Private Sector, Institutions of Higher Education, and Immigrant Settlement in Canada
}

Emma Flynn and Harald Bauder RCIS Working Paper No. 2013/9

December 2013

SERIES EDITOR

Harald Bauder

Ryerson Centre for Immigration \& Settlement Ryerson University Jorgenson Hall, 620 350 Victoria Street, Toronto, ON M5B2K3 http://www.ryerson.ca/rcis 


\title{
RCIS Working Paper
}

No. $2013 / 9$

\section{The Private Sector, Institutions of Higher Education, and Immigrant Settlement in Canada}

\author{
Emma Flynn \\ Ryerson University \\ Harald Bauder \\ Ryerson University
}

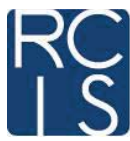

RCIS Working Papers present scholarly research of all disciplines on issues related to immigration and settlement. The purpose is to stimulate discussion and collect feedback. The views expressed by the author(s) do not necessarily reflect those of RCIS. For a complete list of RCIS publications, visit www.ryerson.ca/rcis

ISSN: 1929-9915

This RCIS Working Paper was presented at the 2013 RCIS conference "Immigration and Settlement: Precarious Futures?" held at Ryerson University, May 15-17, 2013. This publication and the conference received funding from the Social Sciences and Humanities Research Council of Canada.

cc) (i) $\Theta($ Creative Commons Attribution-Noncommercial-No Derivative Works 2.5 Canada License 


\begin{abstract}
The settlement sector in Canada has undergone significant transformations in recent times, most notably the imposition of neoliberal principles on service providers that has transferred a substantial amount of the immigrant selection and recruitment process from governmental agencies to third parties. This trend of devolution has accelerated with recent developments associated with Provincial Nominee Programs. By reviewing the literature related to Provincial Nominee Programs and their implementation, we illustrate how private employers and institutions of higher education are not only involved in immigrant selection but also increasingly in settlement service delivery.
\end{abstract}

Keywords: immigration, settlement services, Provincial Nominee Program, neoliberalism, privatization, institutions of higher education, Canada

\title{
Introduction
}

The Canadian immigrant and settlement landscape is changing. Although a large proportion of immigrants continue to settle in Canada's three largest cities Montreal, Toronto, and Vancouver - geographical settlement patterns are shifting towards cities and provinces that have in the past received relatively few immigrants (Di Biase \& Bauder, 2005; Statistics Canada, 2010). Much of this shift has been driven by Provincial Nominee Programs (PNPs), which enable provinces to participate in the selection of immigrants.

There has been no shortage of critiques of the PNPs for inefficiency and lack of accountability (Baglay, 2012; McDonough, 2008; Leo \& August, 2009; Baxter, 2010; Carter et al., 2010; Dobrowlsky, 2011), but less attention has been paid to the neoliberalisation of settlement service provision that came along with the implementation of the PNPs. Canada's recent immigration approach has transferred a substantial amount of the immigrant selection and recruitment process to third parties, aiming to strengthen Canada's economy and global competitiveness (Canada's Economic Action Plan, 2013; Bauder, 2006). This transformation is not limited to the recruitment and attraction of immigration, but it also includes settlement services. Academic literature has extensively documented how the settlement sector is in the midst of shifting the provision of services to non-state actors, demonstrating the Canadian trajectory toward neoliberal principles of competition, flexibilization, and audit controls (Richmond \& Shields, 2005; Baxter, 2010; Lewis, 2010; Palacio, 2010; Cragg, 2011; Dobrowolsky, 2011). To further these studies, in this paper we argue that the neoliberalization of settlement provision is elevated to yet a new level through the privatization of settlement services and the enlisting of institutions of higher education in the delivery of settlement services.

In the sections below, we first present essential background information by reviewing the concepts of neoliberalism, privatization, and regionalization, and by introducing the structure of the PNPs. Then we discuss the existing Canadian 
model of immigrant service delivery before exploring the emerging model that involves employers and institutions of higher education. We close the paper with a discussion of these developments.

\section{Background}

\section{Neoliberalism and Privatization}

The term neoliberalism describes a set of practices and "ideological beliefs" that have become prominent since the 1970s, and which focus on "liberating individuals from the fetters of the state and emphasizing the importance of the market" (Cragg, 2011: 65). Neoliberalism in the twenty-first century continues to influence contemporary politics and society, having a significant effect on the making of public policy within all levels of the government. As David Harvey (2007: 3) explains, "almost all states, from those newly mined after the collapse of the Soviet Union to old-style social democracies and welfare states such as New Zealand and Sweden, have embraced some version of neoliberal theory." Canada is no exception in incorporating neoliberal ideology in the nation's public policy, including immigration and settlement policy.

A pivotal objective of neoliberalism is the privatization of public services. Privatization appears to be "doubly beneficial" through neoliberal perspectives as it "reduces government spending, and it opens potentially lucrative new terrain for private, profit-seeking investment" (Stanford, 2008: 250). The late twentieth century witnessed a trend of service provision shifting from public monopolies to markets operating under the competition principle (Hermann \& Flecker, 2013). This privatization has been presented as a "win-win situation" that is supposed to "lower costs and improve public service quality" (Hermann \& Flecker, 2013: 1).

Canada's immigration system has followed this trend of neoliberalization and privatization. It increasingly embraces employer-driven routes towards residency, and allows employers to pick suitably trained foreign workers from a pool of applicants. Settlement services, too, are embracing neoliberal principles: an increasingly privatized immigrant settlement system has been pursued, relieving the federal government of much of its responsibility and accountability in helping to ensure the success of immigrants entering Canada. James Frideres (2006: 7) remarks "since the 1980's there has been a restructuring of the welfare state in favour of the neo-liberal approach that rejects state intervention with regard to immigrant integration." In particular, the PNPs exemplify Canadian immigration policy's growing reliance on neoliberal ideology, as "these programs enable provincial governments, in close partnership with private employers and other non-governmental actors, to nominate economic immigrants and their dependents for permanent residency" (Baxter, 2011: 2). Likewise, PNPs have also facilitated a shift of the settlement of immigrants from public and not-forprofit service providers to private sector actors. Before we examine PNPs in greater detail, however, we will first discuss the "regionalization" approach that framed the development and implementation of PNPs. 


\section{Regionalization}

In 2001, Citizenship and Immigration Canada's (CIC) published the report Towards a More Balanced Geographic Distribution of Immigrants. This report discussed what both the federal and provincial jurisdictions could do to promote the dispersal of immigrants away from Canada's first-tier cities towards secondand third-tier cities, as well as to rural and remote areas (CIC, 2001). The promotion of regional immigration was influenced by the need to tackle population decline in rural areas, as well as helping to boost "regional economic development" in otherwise non-traditional immigrant receiving communities (Walton-Roberts, 2007: 14). Although immigrants in smaller Canadian cities and towns tend to have higher incomes than immigrants in a gateway city (Bauder, 2003), this task of dispersing immigrants to second- and third-tier cities as well as rural and remote areas is challenging, as the majority of immigrants prefer to live in large cities (Hyndman et al., 2006). These efforts to disperse immigrants have been referred to as "regionalization" (Frideres, 2006; Bruce, 2007; WaltonRoberts, 2007).

It is important to note that regionalization policies are not necessarily associated with neoliberal ideology or practice. In fact, the attempt to manage the geographical distribution of settlement seems to contradict neoliberal market ideology, which would permit immigrants to freely locate in places where the demand for their labour is greatest. From this neoliberal perspective, regionalization policies are a distortion of the free market. Nevertheless, this paper will argue that the manner in which regionalization policies and programs were implemented helped the federal and provincial governments to enact neoliberal principles.

\section{Provincial Nominee Programs}

The most important initiative promoting regionalization has been the PNPs (Baxter, 2010; Carter et al., 2010; Lewis, 2010; Pandey \& Townsend, 2010). Canada's immigration system has traditionally admitted permanent residents through federal immigration programs. PNPs have enabled provinces and territories to "address short-term labour shortages that are not currently being met through the federal skilled worker program" (Carter et al., 2010: 4). In the words of CIC (2013a: n.p.), it is essential that the nominees have "the skills, education, and work experience needed to make an immediate economic contribution to the province or territory that nominates them." The PNPs shift immigrant selection to the provincial level, and gives provincial governments a voice in what kind of immigrants the province needs in terms of labour and skill. However, the federal government "retains primary control over setting national immigration policy by defining classes of admissibility and inadmissibility, and by ensuring that Canada meets its international obligations with respect to refugees" 
(Baxter 2010: 18). Table 1 displays a snapshot ${ }^{1}$ of the immigration streams that the provinces and territories offer. "Other" includes distinct regional streams such as Alberta's Self Employed Farmer Stream or Nova Scotia's Community Identified Nominee programs.

Since Canada's provinces and territories differ tremendously in labour needs, population growth levels, and other factors, the federal government allows the provinces and territories to customize their PNPs to suit regional economic, demographic, and social circumstances. The first federal-provincial immigration accord was with Quebec. The Canada-Quebec Accord was signed in 1991 and provided a provincial immigration scheme that gives Quebec greater power in immigration selection (Baxter, 2010). The Canada-Quebec Accord, however, will be not taken into account in this paper, as it differs substantially from the PNPs.

Table 1- Different PNP streams offered in Canadian provinces and territories

\begin{tabular}{|l|c|c|c|c|c|c|}
\hline $\begin{array}{l}\text { PNP } \\
\text { Streams }\end{array}$ & $\begin{array}{l}\text { Skilled } \\
\text { Worker }\end{array}$ & $\begin{array}{l}\text { Semi- } \\
\text { Skilled } \\
\text { Worker }\end{array}$ & $\begin{array}{l}\text { International } \\
\text { Graduate } \\
\text { Student }\end{array}$ & $\begin{array}{l}\text { Business } \\
\text { Investor/ } \\
\text { Entrepreneur }\end{array}$ & Family & $\begin{array}{l}\text { Other } \\
(\mathrm{s})\end{array}$ \\
\hline BC & $\mathrm{X}$ & $\mathrm{X}$ & $\mathrm{X}$ & $\mathrm{X}$ & & $\mathrm{X}$ \\
\hline $\mathrm{AB}$ & $\mathrm{X}$ & $\mathrm{X}$ & & & & $\mathrm{X}$ \\
\hline SK & $\mathrm{X}$ & & $\mathrm{X}$ & $\mathrm{X}$ & $\mathrm{X}$ & $\mathrm{X}$ \\
\hline MB & $\mathrm{X}$ & & $\mathrm{X}$ & $\mathrm{X}$ & $\mathrm{X}$ & $\mathrm{X}$ \\
\hline ON & $\mathrm{X}$ & & $\mathrm{X}$ & $\mathrm{X}$ & & \\
\hline NB & $\mathrm{X}$ & & & $\mathrm{X}$ & $\mathrm{X}$ & \\
\hline PEI & $\mathrm{X}$ & $\mathrm{X}$ & & $\mathrm{X}$ & & \\
\hline NS & $\mathrm{X}$ & & & $\mathrm{X}$ & $\mathrm{X}$ & $\mathrm{X}$ \\
\hline NL & $\mathrm{X}$ & & $\mathrm{X}$ & $\mathrm{X}$ & & \\
\hline NWT & $\mathrm{X}$ & $\mathrm{X}$ & & $\mathrm{X}$ & & \\
\hline YT & $\mathrm{X}$ & $\mathrm{X}$ & & & & \\
\hline SOE: Stan
\end{tabular}

Source: Streams identified through provincial and territorial PNP websites, August 2013

Before the PNPs were implemented, some provinces and territories had distinct agreements with the federal government pertaining to immigration. The PNPs differ from these agreements in that it gives the provincial and territorial governments a "formal role in the selection of immigrants" (Carter et al., 2010: 6). The first PNPs were signed in 1998 by British Columbia, Manitoba, and Saskatchewan followed by New Brunswick (1999), Newfoundland and Labrador (1999), Alberta (2002), Nova Scotia (2002), Prince Edward Island (2002), and Ontario (2007). Each PNP created its own immigration streams (Carter et al., 2010). Additionally, the territories have created their own programs with Yukon starting in 2001 and the Northwest Territories in 2009 (Carter et al., 2010). Nunavut and Quebec are the only exceptions that do not have PNP streams of immigration. Over the last decade, the PNP has become the second largest route

\footnotetext{
${ }^{1}$ PNP streams are in constant flux as provinces and territories experiment with different alternatives.
} 
to economic immigration to Canada. In 2011 more than 38,000 provincial nominees, inclusive of spouses and dependents, entered Canada (CIC, 2012a). It is also the main vehicle for immigrants into Manitoba, Prince Edward Island, Saskatchewan, and New Brunswick (CIC, 2012a).

The PNPs pioneered the practice of allowing employers to sponsor temporary foreign workers (TFW) as provincial nominees through either the skilled or semi-skilled streams. These programs are thus attractive for employers who want to keep their TFWs permanently after their initial visas expire. In this case, provincial and territorial government officials determine if the applicant meets the criteria for the stream through which they are applying (Carter et al., 2010). Once a worker is nominated, CIC requires a background check relating to health, criminality, and security before granting immigration status (Carter et al., 2010).

In addition, international Master's and PhD students may become permanent residents via the numerous PNP international graduate student streams across the country. A province may nominate the student if they have recently graduated from an existing graduate program within the province (normally within two years), have legal immigration status in Canada, and have intentions of remaining within province, among other stipulations. This program benefits both international students who wish to remain in Canada and gain permanency, as well as the province, which aims to acquire young, educated individuals who will ideally settle permanently in the province.

Although PNPs aim to regionalize immigration, the programs cannot restrict successful nominees from moving to other provinces. Section 6 , point 2 of the Canadian Charter of Rights and Freedoms states: "Every citizen and every person who has the status of a permanent resident of Canada has the right a) to move to and take up residence in any province; and $b$ ) to pursue the gaining of a livelihood in any province" (Government of Canada, 1982). PNPs may entice prospective immigrants to apply to a certain province or territory, but this does not necessarily mean that they will remain there (Hou, 2007). Table 2 displays the varying retention rates of nominee principal applicants by province. To increase rates of immigrant retention, more effective settlement services need to be provided. In the next section, we examine the current state of settlement service delivery.

\section{Settlement Services}

The delivery of settlement services involves multi-level governance "in the form of fiscal resources, cooperation agreements, or provisions for power sharing" (Tolley, 2011: 4). The federal government presently funds the majority of settlement services involving multiple "delivery streams" (i.e., Information and Orientation, Language and Skills Development, Labour Market Participation, Community Connections, Needs Assessments and Referrals, Support Services, and Indirect Services), and "settlement program outcomes" (i.e., Orientation, Language/Skills, Labour Market Access, Welcoming Communities, Policy and Program Development) (CIC, 2012c). Federal funding for settlement has tripled 
Table 2 -Retention of PNP Principal Applicants of each province (2000-

\begin{tabular}{|l|l|l|}
\hline $\begin{array}{l}\text { Province or } \\
\text { Territory }\end{array}$ & Number of PA PN & $\%$ of PA PN's Retained \\
\hline NL & 255 & 22.9 \\
\hline PEI & 885 & 36.6 \\
\hline NS & 785 & 65.4 \\
\hline NB & 1,065 & 65.1 \\
\hline ON & 45 & -- \\
\hline MB & 11,515 & 82.6 \\
\hline SK & 20,65 & 86.0 \\
\hline AB & 1,975 & 95.3 \\
\hline BC & 2,975 & 96.4 \\
\hline
\end{tabular}

Source: PNP Evaluation: CIC (2011: 8 \& 53)

Note: ON, NWT, and YK were not included due to their small numbers in nominees

in the past decade (CIC, 2012d). Manitoba, British Columbia, and Quebec have established their own federal-provincial settlement service agreements, facilitating a federal transfer of funds to the provincial governments that then have control over the design and development of settlement services. CIC, however, has recently suspended the agreements with Manitoba and British Columbia and by 2014 will repatriate all settlement service funding, with the exception of Quebec.

At the provincial level, Quebec has long played a key role in immigrant settlement since the establishment of its own Department of Immigration in 1968, and continues to do so with its Canada-Quebec Accord (Baxter, 2010; Chiasson $\&$ Koji, 2011). The other provinces have the flexibility to add distinct programs if the province formally requests it, such as New Brunswick's francophone settlement program. In addition, all provincial and territorial governments offer provincial immigration and settlement websites.

Municipal governments are also involved in settlement as immigrants search for accommodation, enroll children in school, and engage in other local activities. However, as "creatures of the provinces" with no direct funding for settlement services, municipalities play a subordinate formal role in immigrant settlement, even though the cities and towns are "the primary recipients of immigrants to Canada" (Tolley, 2011: 4). The 2005 Canada-Ontario-Toronto Immigration Agreement and the 2006 Canada-Ontario-Toronto Memorandum of Understanding (MOU) on Immigration and Settlement has given the city of Toronto more immigrant settlement responsibility (Stasiulis et al., 2011). In 2007, Edmonton followed suit to become the second Canadian municipality with such an agreement (Tossutti, 2012). Toronto further blazed the path towards migrant inclusion when its City Council voted to effectively declare itself a "Sanctuary City". This new policy allows "illegalized" migrants (Bauder, 2013b) living in Toronto to access municipal services without fear of detention and deportation (Bauder, 2013a; Dhillon, 2013). Second- and third-tier cities and towns participate in immigrant settlement as well (Chiasson \& Koji, 2011), though 
through less direct policy-driven initiatives. For example, Sherbrook City Council has created an "Intercultural Relations and Diversity Committee", and the town of Rimouski has developed a "Welcoming Guide for Newcomers" and has adopted the "Rimouski Declaration of the Citizens Rights" (Chiasson \& Koji, 2011). These new developments, however small or large they may be, are symbolic of the municipalities' commitment to the settlement and integration of newcomers into their communities.

Although federal, provincial, and municipal governments provide much of the funding for settlement services, the majority of the support and services are delivered by immigrant service providers (ISPs), which receive funds from all levels of government and other stakeholders. ISPs perform a role that Jennifer Wolch (1990) has called the "Shadow State", serving as a "parallel system comprised of non-government organizations (NGOs) that deliver collective services formerly provided by state-run agencies" (Sadiq, 2004: 4). Along these lines, Kareem Sadiq (2004: 1) argues that "Canada's settlement sector has evolved into a para-state system that is financed by contractual arrangements between the state and non-governmental settlement agencies" to deliver employment, language, housing, education, and other services to newcomers. This type of restructuring of the settlement sector has created instability, service gaps, as well as "a general diversion of precious human resources from service planning and delivery to irrational administrative burdens" (Richmond \& Shields, 2005: 518; Evans et al., 2005). This non-centralized service structure also further aggravates the spatial mismatch between where immigrants are located and where services are offered (Sadiq, 2004; Lo et al., 2007; Joassart-Marcelli, 2013). This gap needs to be addressed in the context of the recent development of PNPs and the associated need for settlement services in non-traditional immigrant reception centres, in which the private sector and institutions of postsecondary education are expected to contribute to improving and expanding existing settlement services.

\section{Emerging Models of Service Delivery}

In recent years, the nature of settlement service delivery has changed considerably. For example, foreign workers under the PNP are not only dependent on employers for their immigration status, but also the provision of settlement services (Rural Development Institute, 2005; Baxter, 2010; Carter et al., 2010; Moss et al., 2010; Palacio, 2010; Cragg, 2011). In particular, the PNPs have "increased reliance on employers to provide language and settlement services, linked with possibilities for creating a vacuum in service provision where governments have derogated public responsibility and when third-party actors are absent" (Baxter, 2010: 3). As the PNPs encourage immigration to nontraditional immigrant receiving areas, where ISPs may not be located, employers are beginning - and in some cases, like Alberta, are expected (see Appendix) to provide settlement services for potential and actual nominees. 
A major settlement service gap neglected by the federal government is the period of transition between when migrant workers or students possess temporary status and when they are nominated for the PNP (Baxter, 2010). During this period, which could be anywhere from eight months to two years, prospective immigrants are not eligible to receive government-funded settlement services. Although provincial governments may be more flexible than the federal government in regulating who is receiving settlement services, the gap in service delivery has remained, resulting in the provision of these services by employers and institutions of higher education.

\section{Employers}

The Rural Employers' Information Pathway for Hiring Temporary Foreign Workers in Manitoba (Zahtab et al, 2010) encourages employers to participate in the settlement process of employees as much as possible by holding diversity and inter-cultural training sessions at the workplace and arranging housing for the foreign workers in the community. The important role of employers is described by Nelson Palacio's (2010) review of low-skilled provincial nominees working at Maple Leaf in Brandon, Manitoba. The employer's roles were very apparent in all aspects of the PNP settlement experience, both for the immigrant and the community. Maple Leaf recruits workers and their families from specific countries that speak particular languages to "ease the settlement planning and integration" (Palacio, 2010: 64). For example, a majority of the TFW in Brandon comes from Spanish-speaking countries, which permits holding group sessions of orientation and language classes that require only a Spanish-to-English translator. Maple Leaf has also gone further by creating a formal settlement plan for nominees, which includes benefits such as "one month's rent, a month-long bus pass, access to the company cafeteria for one week, vouchers to purchase food, etc." (Palacio, 2010: 64). Although Maple Leaf is doing good work on optimizing their settlement services, concerns have been raised about the unsanitary conditions of the accommodation provided (Palacio, 2010). Yet it is not surprising that these conditions have not made headlines since the employment contracts of the workers are tied to their status, putting these workers in vulnerable positions until their nomination process is complete and they are granted permanent immigration status. This example demonstrates that although private employers are putting considerable effort into their PNP experience, there is still much work to do in order to ensure that the private sector is accountable for the quality of their settlement services.

Kataoke \& Magnusson (2011) conducted another case study about immigration to Kelowna, British Columbia. They found that employers have taken a leading role in nominee settlement. For instance, a key employer in the city has been providing nominees with rental housing and a comprehensive welcome package. The Economic Development Commission of Kelowna has gone so far as to hire a staff person who has previous experience working for $\mathrm{ClC}$ that can support nominees in filling out immigration paperwork and referring them to different programs that would be useful in their settlement process (Kataoke \& 
Magnusson, 2011). In this example, both employers and community stakeholders have taken settlement provision into their own hands.

At the debut of Nova Scotia's PNP, the premier of the province declared that the program would be at "no extra cost to the tax payers of the province." Accordingly, the program was designed to hold both the nominees and their private employers accountable for the attraction and settlement of the newcomers (Haddow, 2011). In particular, the province made a contract with a consulting firm, Cornwallis Financial Corporation, to execute the economic and business mentorship responsibilities (Haddow, 2011). The economic category of the Nova Scotia PNP that was hosted by the private company failed quickly (McDonough, 2008; Dobrowlsky, 2011; Dobrowlsky, 2012). Challenges that arose included that "the majority of business matches are not bona fide, the employment relationships which are legitimate are rarely at a middle management level as required and many of the nominees are not staying in Nova Scotia, and those that stay indicate that the program does not meet their needs." At the same time, Cornwallis Corporation "raked in almost \$4 million without much show for its efforts" (Gillis, 2005: 8, cited by Dobrowlsky, 2012: 206). Because the contract was not renewed, Cornwallis sued the Nova Scotia provincial government for "defamation, breach of contract and financial compensation" (Dobrowlsky, 2012: 206). The economic program was terminated in 2006 (McDonough, 2008; Dobrowlsky, 2012). This example demonstrates that the province must closely monitor private stakeholders in order to maintain the integrity of the program and properly match nominees with relevant employers.

In Alberta's lower-skilled nominee streams, the employers are required to fill out an Employer-Driven Settlement and Retention Plan (AINP, 2013, see Appendix). On the form, employers are expected to offer English as a Second Language (ESL) instruction as well as the option of providing accommodation, transportation, school enrollment for children, health care services, and financial services (AINP, 2013). The provincial government asks employers to assume responsibility for settlement services for the foreign workers they are recruiting, but these employers are given a large amount of control over these services without proper evaluation or accountability.

This privatization of settlement services occurs in a context in which there may be no other options, as ISPs are often absent from smaller towns and remote areas where companies with the need for TFWs are located. The nominees' work schedule, which may include long hours and laborious work, may also not permit travel to locations where services may be offered. Baxter (2010: 39) suggests that the employers' heavy participation in the nominees' settlement could have positive outcomes such as "increasing employer-worker communication, building mutual respect, and strengthening norms of loyalty and reciprocity that promote worker retention." However, Baxter (2010) also acknowledges that the lack of public involvement puts the employee in a vulnerable position, and the employer may be enticed to exploit these vulnerabilities. 


\section{Institutions of Higher Education}

The road to permanency through PNPs can also involve studying at a Canadian institution of higher education, as well as an application through provincial streams that target international students. Each provincial international graduate stream is unique as certain PNPs require Canadian work experience, some are employer-driven, and others require in-province education for sponsorship (Gates-Gasse, 2012). Similar to temporary foreign workers, international students (along with their spouses and dependents) are ineligible for federally funded settlement services until they are granted permanent residency, which could take up to ten years after entering the country to study (Gates-Gasse, 2012).

Heather Moore (2008) examines the student-to-immigrant experience through a case study at York University in Ontario. According to Moore (2008), the process for international students to become a permanent resident can be overwhelming, which may be a reason that so many international students do not pursue permanency. While one key informant noted that the campus community's social network and informal advice led him through the process towards permanency, formal university institutions such International Student Offices (ISOs) are also a focal point for international students to become orientated at the university and to seek academic support and employment.

Although there have been instances of mentoring programs that link international students with members of the community for professional networking, universities and other institutions of higher education have the potential to assume an even greater role in delivering programs to help students achieve permanent residency (Gates-Gasse, 2012). A practical example of a university becoming involved in the settlement and integration of the students and potential nominees is Newfoundland's Memorial University, which receives a grant from the provincial government to deliver the Professional Skills Development Program for International Students as well as a Family Integration Support Program (Gates-Gasse, 2012). These programs' main goal is to retain international students by educating them on Canadian employment culture and practice, by helping them make connections in the community, and by providing their families with integration support through information and referrals in the community (Gates-Gasse, 2012). Similarly, L'universite de Moncton in New Brunswick has delivered a program titled "Destination Emploi", which seeks to retain Francophone international students as residents in the province (GatesGasse, 2012). The program helps international students enter the workforce and provides "additional coaching to students during their studies and assisting them with social integration into the community, encouraging New Brunswick businesses to hire international students, and educate students who are about to graduate about how to immigrate to the province" via the PNP (Gates-Gasse, 2012: 284). These programs are located at the university campuses, funded provincially, and staffed through the university. Universities are recognizing that this kind of settlement and employment services are essential to these international students who aim to acquire permanent residency. 
Yet another study examined service needs and gaps for international postsecondary students transitioning to permanent residency in Toronto, Ontario. The interviews conducted with international student advisors revealed how dynamic their role is in this process: advisors not only provide information on how to obtain a work permit, but also deal with "immigration, academic issues, personal issues, transition issues, relationship issues, sometimes housing issues, or career" (Roach, 2011: 28). These efforts are complemented by CIC, providing workshops on pathways and procedures to permanent residency and bridging services to connect students to community organizations in the university setting (Roach, 2011).

\section{Discussion and Conclusion}

As Canadian immigration policies change to increase the input from provinces in the selection of immigrants, dependence on the private sector and institutions of higher education for settlement provision has also grown. This dependence, however, is not equal across Canada. Since there is no national settlement policy that specifies what settlement services must be provided to newcomers (regardless of where they are settling), a multi-tier system of settlement provision has emerged that differentiates between 1) immigrants in cities and traditional centres of reception who receive settlement services from ISPs, 2) immigrants in non-traditional settlement areas who receive settlement services from the private sector, and 3) prospective immigrants who are student at institutions of higher education.

Although our study has focused primarily on provincial and territorial nominees, the phenomenon of privatizing settlement services may also occur in light of the immanent restructuring of federal immigration programs. The new immigration approach "Expression of Interest" (EOI) implements a "fast and flexible economic immigration system whose primary focus is on meeting Canada's labour needs" (CIC 2012b: 1), with intentions to "explore with provinces, territories and employers approaches to developing a pool of skilled workers who are ready to begin employment in Canada" (CIC, 2013b: 1). The new immigration approach, which is expected to commence by the end of 2014, will allow employers to "cherry-pick" potential immigrants to fill labour shortages from a pool of skilled-worker candidates and, expectantly, have them in the labour market faster than existing immigration streams. The former immigration minister, Jason Kenney, stated that foreign workers "will go into this pool, and then employers or my department and or provinces will be able to fish out of that pool, it's like a dating site" (Chase, 2013: 1). Clearly, Canadian immigration is heading in a direction that gives employers greater influence in selecting immigrants. Our research has shown that the Canadian government's invitation to businesses to be partners in the immigrant selection process is also associated with granting them a greater role in settlement provision.

Neoliberal ideology is becoming more prominent in Canadian immigration and settlement policy. Competition has arisen between provinces and 
municipalities in immigrant attraction and retention through settlement provision. In addition, PNPs are designed to relieve government from settlement service provision by enlisting the help of and mobilizing resources from employers and institutions of higher education. From a practical viewpoint, this offloading of settlement responsibilities can be counterproductive to the aims of regionalization. As players who have not traditionally been involved in settlement services attempt to fill the provision gaps, concerns have mounted regarding the effectiveness of service provision and its consequences. A failed integration process at the local scale due to inadequate settlement services may lead to newcomers and their family to relocate elsewhere, which would defeat one of the main purposes of the PNPs.

More worrying, however, is the continuation of the shift towards neoliberal practices in settlement service provision. While over the last decade or so, the system through which ISPs delivered services to immigrants was restructured along neoliberal ideology, the most recent trend suggests that settlement services may be taken out of the purview of ISPs altogether and allocated to the private sector and institutions of higher education - neither of which has a mandate or specialized expertise to deliver such comprehensive settlement services.

\section{Acknowledgements}

We thank John Shields for feedback. 


\section{Appendix - Alberta Immigrant Nominee Program: Employer-Driven Settlement \& Retention Plan Form}

Alberta Immigrant Nominee Program

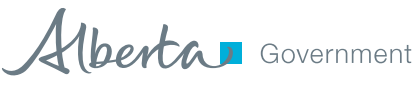

\section{Employer-Driven Settlement \& Retention Plan}

This form is designed to help employers develop and document a settlement and retention plan for workers arriving from other countries.

Settlement

1. Are you providing accommodations for your foreign workers? $\square$ Yes $\quad \square$ No (go to question 2)

If yes, provide information for the place of residence:

\begin{tabular}{l|l|l}
$\begin{array}{l}\text { Number of tenants living in the } \\
\text { residence? }\end{array}$ & $\begin{array}{l}\text { Number of bedrooms and } \\
\text { bathrooms? }\end{array}$ & Size of residence? (i.e. square footage) \\
\hline Address & Rate of monthly rent? & $\begin{array}{l}\text { Is the residence owned by the employer } \\
\text { or anyone directly associated with the } \\
\text { employer? }\end{array}$ \\
& $\begin{array}{l}\text { Is rent deducted from the } \\
\text { Candidate's pay? } \\
\square \text { Yes } \square \text { No }\end{array}$ & \begin{tabular}{l}
$\square$ Yes $\square$ No \\
\hline
\end{tabular}
\end{tabular}

2. If you are not providing accommodation, how are you helping your foreign workers find reasonable housing?

3. How have you formally assessed your foreign worker's ability to read, write, speak, and listen in English proficiently? (for more details about language ability, see Semi-Skilled Worker Category - Language Criteria)

4. Have you arranged for your foreign workers to attend English as a Second Language (ESL) instruction?

$\square$ Yes $\quad \square$ No Visit www.tesl.ca to find out more about certified ESL instructors

If yes, answer the applicable questions and include a copy of the Candidate's registration(s) for program(s). If no, explain why there is no ESL instruction:

\begin{tabular}{|c|c|c|}
\hline $\begin{array}{l}\text { Where is the location of the language training? } \\
\square \quad \text { At the location of employment }\end{array}$ & $y$-based & Levels offered? \\
\hline Number of weeks? & Number & sses per week? \\
\hline Number of hours per class? & Daytime & ning classes? \\
\hline $\begin{array}{l}\text { Name of the agency/instructor responsible for providing } \\
\text { the ESL training? }\end{array}$ & How are & sts of the training covered? \\
\hline
\end{tabular}

AINP Employer-Driven Settlement \& Retention Plan (2012/06) 
5. What information/resources/support will you provide to your foreign workers for each of the following:

\begin{tabular}{l|l}
\hline $\begin{array}{l}\text { Transportation? (i.e. getting to/from work, grocery stores } \\
\text { and other services) }\end{array}$ & Purchasing food/personal items? \\
\hline Accessing financial services/opening a bank account? & Children's school enrollment? \\
\hline Health care services? & \\
\hline & $\begin{array}{l}\text { Other information to improve comfort and familiarity with } \\
\text { the workplace and community? }\end{array}$
\end{tabular}

Workers will receive health care coverage from the date they arrive in Alberta as long as they apply within three months of their arrival and meet Alberta Health Care's requirements. For workers not eligible, employers should explore private medical insurance plans. www.health.gov.ab.ca

6. How will you ensure that new foreign workers are fully aware of their workplace rights? (i.e. workplace safety and employment standards information)

7. What community agencies in your area are available to help newcomers? What are you doing to ensure they have access to these agencies?

Retention

1. What type of employment benefit plan do you offer to all employees?

2. What opportunities are provided to employees for training?

3. What opportunities are provided to employees for career advancement?

4. How are employees encouraged to maintain a work/life balance? 
5. How often are performance reviews conducted with employees?

6. Explain how and when an employee becomes eligible to receive an increase to their wage.

7. What employee recognition practices/programs are in place? (i.e. service and/or performance based)

8. What opportunities are employees given to organize and participate in various company activities? (i.e. company BBQ's, cultural/holiday gatherings, sports teams, etc.)

9. Has your company had any layoffs within the last 12 months? $\square$ Yes $\square$ No If yes, list the number of layoffs, the dates they occurred, as well as how many were temporary foreign workers.

10. Has your company participated in a wage subsidy program (i.e. Work-Sharing Program) within the last 12 months or expect to be participating in a program? $\square$ Yes $\square$ No

Note:

The Work-Sharing Program is administered by Service Canada and is designed to help employers and workers avert temporary layoffs. The program provides income support to workers eligible for Employment Insurance benefits and who are willing to work a temporary reduced work week when there is a reduction in the normal level of business activity that is beyond the control of the employer.

11. Have any of your employees previously been nominated by the AINP? $\square$ Yes $\square$ No If yes, please provide a list of the previously nominated candidates, and their current employment status with your company. If any nominated candidates are no longer employed with your company, please provide the reason for separation and where they are currently live and work (if known).

Source: AINP (2013) 


\section{References}

Alberta Immigrant Nominee Program (AINP). 2013. Employer-driven settlement \& retention plan. Alberta Government. Retrieved from website: https://www.albertacanada.com/AINP-EDS-SettlementRetentionPlan.pdf

Baglay, S. 2012. Provincial nominee programs: A note on policy implications and future research needs. Journal of International Migration \& Integration, 13(1), 121-141.

Bauder, H. 2003 Immigrants in Urban Labour Markets: Place of Birth and Immigrant Concentrations in British Columbia. Canadian Journal of Urban Research 12(2): 179-204

Bauder, H. 2006. Labor Movement: How Migration Regulates Labor Markets. New York: Oxford University Pres.

Bauder, H. 2013a. Sanctuary City: Toronto's signal to Ottawa and Queen's Park. The Toronto Star, Feb. 27. Retrieved from:

http://www.thestar.com/opinion/editorialopinion/2013/02/27/sanctuary city torontos signal to ottawa and queens park.html

Bauder, H. 2013b. Why We Should Use the Term Illegalized Immigrant. RCIS Research Brief 2013 No. 1. Retrieved from:

http://www.ryerson.ca/content/dam/rcis/documents/RCIS_RB_Bauder_No 2013_1.pdf

Baxter, J. 2010. Precarious pathways: Evaluating the Provincial Nominee Programs in Canada. A research paper for the Law Commission of Ontario. Retrieved from: http://www.ontla.on.ca/library/repository/mon/24012/306589.pdf

Bruce, D. 2007. The challenge of immigration as a rural repopulation strategy in Maritime Canada. Our Diverse Cities , 3, 90-96. Retrieved from http://canada.metropolis.net/pdfs/ODC Summer07 3 en.pdf

Canada's Economic Action Plan , 2013. Strengthening Canada's immigration system. Retrieved from website:

http://actionplan.gc.ca/en/initiative/strengthening-canadas-immigrationsystem

Carter, T., Pandey, M., \& Townsend, J. 2010. The Manitoba Provincial Nominee Program: Attraction, Integration and Retention of Immigrants. Institute for Research on Public Policy (10), 1-44.

Chase, S. 2013. Ottawa to play matchmaker for foreign workers. The Globe and Mail. Retrieved from http://www.theglobeandmail.com/news/politics/ottawa-to-playmatchmaker-for-foreign-workers/article6840232/

Chiasson, G., \& Koji, J. 2011. Quebec immigrant settlement policy and municipalities. In Immigrant settlement policy in Canadian municipalities edited by E. Tolley \& R. Young. McGill-Queen's University Press.

CIC, 2001. Citizenship and Immigrant Canada, (2001) Towards a More Balanced Geographic Distribution of Immigrants. Cat. no. CI51-109/4- 2002E. Ottawa: Minister of Public Works and Government Services Canada.

CIC, 2011. Citizenship and Immigration Canada, Evaluation Division. (2011). Evaluation of the Provincial Nominee Program. Catalogue No. 
ER201110.01E. Ottawa: Minister of Public Works and Government Services Canada.

CIC, 2012a. Citizenship and Immigration Canada, (2012). Fact sheet- provincial nominee program. Retrieved from website:

http://www.cic.gc.ca/english/resources/publications/employers/provincialnominee-program.asp

CIC, 2012b. Federal, provincial, and territorial governments envision Canada's future immigration system. (2012). Citizenship and Immigration CanadaNews Release . Retrieved from http://www.cic.gc.ca/english/department/media/releases/2012/2012-1116.asp

CIC, 2012c. Citizenship and Immigration Canada,(2012). Funding guidelines: national call for proposals- 2012 grants and contributions settlement and resettlement programs. Retrieved from website: http://www.cic.gc.ca/english/department/grants-contributionsfunding/documents/pdf/cfp-guidelines-2012.pdf

CIC, 2012d. Citizenship and Immigration Canada, (2012). The government of Canada invests record funding for settlement services for newcomers to Manitoba. Retrieved from website: http://www.cic.gc.ca/english/department/media/releases/2012/2012-1213b.asp

CIC, 2013a. Citizenship and Immigration Canada, (2013). Provincial nominees. Retrieved from website: http://www.cic.gc.ca/english/immigrate/provincial/index.asp

$\mathrm{CIC}, 2013 \mathrm{~b}$. The role of employers in an expression of interest system. (2013, 03 26) Citizenship and Immigration Canada- Consultations Retrieved from http://www.cic.gc.ca/english/department/consultations/eis/index.asp

Cragg, A. 2011. Neoliberalising immigration in Canada: the pilot project for occupations requiring lower-levels of formal training and the expansion of Canada's temporary foreign worker program. (Master's thesis, Trent University ).

Di Biase, S. \& Bauder H. 2005. Immigrant Settlement in Ontario: Location and Local Labour Markets. Canadian Ethnic Studies 37(3): 114-135.

Dhillon, S. 2013. Toronto officially opens services to undocumented residents. The Globe and Mail. Retrieved from http://www.theglobeandmail.com/news/toronto/toronto-officially-opensservices-to-undocumented-residents/article8964530/

Dobrowolsky, A. 2012. Nuancing Neoliberalism: Lessons Learned from a Failed Immigration Experiment. Journal of International Migration \& Integration, 87, 109-142

Dobrowolsky, A. 2011. The Intended and Unintended Effects of a New Immigration Strategy: Insights from Nova Scotia's Provincial Nominee Program. Studies in Political Economy, 87, 109-141.

Evans, B., Richmond, T., \& Shields, J. 2005. Structuring neoliberal governance: the nonprofit sector, emerging new modes of control and the marketisation of service delivery. Policy and Society, 24(1), 73-97. 
Frideres, J.S. 2006. "Cities and Immigrant Integration: The Future of Secondand Third-Tier Centres." Our Diverse Cities 2: 3-8.

Gates-Gasse, E. 2012. International students as immigrants. In Immigration and Settlement: Challenges, Experiences and Opportunities edited by $\mathrm{H}$. Bauder. 271-295. Toronto: Canadian Scholars' Press Inc.

Government of Canada, 1982. Canadian charter of rights and freedoms. Ottawa, Canada

Haddow, R. 2011. Multilevel governance and immigration policy in Nova Scotia. In Immigrant Settlement policy in Canadian municipalities edited by E. Tolley \& R. Young, pp. 192-241. McGill-Queen's University Press.

Harvey, D. 2007. Brief History of Neoliberalism. Oxford: Oxford University Press. Hermann, C. \& Flecker, J. 2013. Privatization of Public Services : Impacts for Employment, Working Conditions, and Service Quality in Europe. Taylor and Francis.

Hou, F. 2007. Changes in the initial destination and redistribution of Canada's major immigrant groups: reexamining the role of group affinity. International Migration Review, (41) 3, 680-705

Hyndman, J., Schuurman, N., \& Fiedler, R. 2006. Size matters: attracting new immigrants to Canadian cities. Journal of International Migration and Integration, 7, 1-25.

Joassart-Marcelli, P. 2013. Ethnic concentration and nonprofit organizations: The political and urban geography of immigrant services in Boston, Massachusetts. International Migration Review, 47(3), 730-772.

Kataoka, S., \& Magnusson, W. 2011. Immigrant settlement policy in British Columbia. In Immigrant Settlement policy in Canadian municipalities edited by E. Tolley \& R. Young. 241-294. McGill-Queen's University Press.

Leo, C., \& August, M. 2009. The multilevel governance of immigration and settlement: making deep federalism work. Canadian Journal of Political Science, 42(2), 491-510.

Lewis, N. 2010. A decade later: assessing successes and challenges in Manitoba's provincial immigrant nominee program. Canadian Public Policy, 36(2), 241-246

Lo, L., Wang, L., Wang, S., \& Yuan, Y. 2007. Immigrant settlement services in the Toronto CMA: a GIS-assisted analysis of supply and demand. CERISThe Ontario Metropolis Centre. CERIS Working Paper No.59.

McDonough, P. 2008. Nova Scotia's provincial immigration policy: the failure of the business mentorship program. Master's Thesis, Ryerson University.

Moore, H. 2008. From Student to Migrant: Migration Narratives of International Students in Canada. Master's Thesis, York University

Moss, A., Bucklaschuk, J., \& Annis, R.C. 2010. Small Places, Big Changes:

Palacio, N. 2010. Integration of low-skilled immigrants through Manitoba's provincial nominee program. (Master's Thesis, Ryerson University).

Pandey, M., Townsend, J. 2010. Provincial nominee programs: An evaluation of earnings and retention rates of nominees. Retrieved from: http://economics.uwinnipeg.ca/RePEc/winwop/2010-01.pdf 
Richmond, T., \& Shields, J. 2005. NGO-government relations and immigrant services: contradictions and challenges. Journal of International Migration and Integration, 6(3/4), 513-526.

Roach, E. 2011. Service needs and gaps for international students transitioning to permanent residency in a "two-step" immigration process: a Torontobased study. (Master's Thesis, Ryerson University)

Rural Development Institute. 2005. Manitoba rural immigration community case studies: Winkler. Working Paper.

Sadiq, K. 2004. The two-tier settlement system: a review of current newcomer services in Canada. CERIS- The Ontario Metropolis Centre. CERIS Working Paper No. 34

Stanford, Jim. 2008. Economics for Everyone: A Short Guide to the Economics of Capitalism. London: Pluto Press..

Stasiulis, D., Hughes, C., \& Amery, Z. 201. From government to multilevel governance of immigrant settlement in Ontario. In Immigrant Settlement policy in Canadian municipalities edited by E. Tolley \& R. Young. McGillQueen's University Press 2011.

Statistics Canada. 2010. Projections of the diversity of the Canadian population. Catalogue No. 91-551-X. Ottawa, Canada.

Temporary Migration, Immigration and Family Reunification. Canadian Issues, Spring 2010, p.33-36.

Tolley, E. 2011. Introduction: Who invited them to the party? Federal-municipal relations in immigrant settlement policy. In Immigrant Settlement Policy in Canadian Municipalities edited by E. Tolley \& R. Young. McGill-Queen's University Press 2011.

Tossutti, L. 2012. Municipal roles in immigrant settlement, integration and cultural diversity. Canadian journal of political science 45(3), 607-633.

Walton-Roberts, B. 2007. Immigration regionalization in Ontario: policies, practices and realities. In Our diverse cities: Ontario edited by K. Graham. 13-19.

Wolch, J. 1990. The Shadow State: Government and Voluntary Sector in Transition. New York: Foundation Centre.

Zahtab-Martin, A., Bucklaschuk, J., \& Ashton, B. 2010. Rural employers' information pathway for hiring temporary foreign workers in Manitoba. Rural Development Institute, Brandon, MB. 